Winter 2012

\title{
International Human Rights in Canadian Immigration Law - The Case of the Immigration and Refugee Board of Canada
}

\author{
Catherine Dauvergne \\ University of British Columbia, Faculty of Law, Catherine_Dauvergne@ubc.ca
}

Follow this and additional works at: https://www.repository.law.indiana.edu/ijgls

Part of the Comparative and Foreign Law Commons, Human Rights Law Commons, Immigration Law Commons, and the International Law Commons

\section{Recommended Citation}

Dauvergne, Catherine (2012) "International Human Rights in Canadian Immigration Law - The Case of the Immigration and Refugee Board of Canada," Indiana Journal of Global Legal Studies: Vol. 19 : Iss. 1 , Article 11.

Available at: https://www.repository.law.indiana.edu/ijgls/vol19/iss1/11

This Symposium is brought to you for free and open access by the Law School Journals at Digital Repository @ Maurer Law. It has been accepted for inclusion in Indiana Journal of Global Legal Studies by an authorized editor of Digital Repository @ Maurer Law. For more information, please contact rvaughan@indiana.edu.

JEROME HALL LAW LIBRARY

INDIANA UNIVERSITY

Maurer School of Law
Blooming ton 


\title{
International Human Rights in Canadian Immigration Law-The Case of the Immigration and Refugee Board of Canada
}

\author{
CATHERINE DAUVERGNE*
}

\begin{abstract}
This article analyzes the use of international human rights in the decision making of Canada's Immigration and Refugee Board. At the center of the analysis is a data set including all the publically available decisions of the Board since the introduction of the 2002 Immigration and Refugee Protection Act. This data set has been coded for varying degrees of engagement with international human rights law, and the results are presented and scrutinized. At the broadest level, the results are disappointing for migrant advocates as international law is relied on in an infinitesimally small number of decisions.
\end{abstract}

\section{INTRODUCTION}

There is every reason to believe that noncitizens in Canada will benefit from robust protection of international human rights. All the conditions seem to be in place. Canada is a state party to almost all of the major international human rights instruments (with the highly notable exception of the Convention on the Rights of All Migrant Workers and Their Families); ${ }^{1}$ Canada has sought out an international

* Faculty of Law, University of British Columbia. Comments to catherine.dauvergne@ ubc.ca. I am grateful to Joyce Bolton and Brian Koh for their work on the data set discussed in this paper, and Robert Russo for his timely and reliable research assistance. I also would like to thank the Social Sciences and Humanities Research Council of Canada for providing funding for this project.

1. There are nine core international human rights instruments listed by the Office of the United Nations High Commissioner for Human Rights. See International Law, OFF. U.N. HIGH COMM'R FOR HUM. RTS., http:/www2.ohchr.org/english/law/index.htm\#core (last visited Dec. 23, 2011). Of the nine core instruments, Canada is a state party to seven. See Convention on the Rights of Persons with Disabilities, Jan. 24, 2007, 993 U.N.T.S. 3 (ratified by Canada on Mar. 11, 2010); Convention on the Rights of the Child, Nov. 20, 1989, 1577 U.N.T.S. 3 [hereinafter CROC] (accepted by Canada Sept. 17, 1997);

Indiana Journal of Global Legal Studies Vol. 19 \#1 (Winter 2012)

(C) Indiana University Maurer School of Law 
leadership role in human rights protections; Canada applies the constitutional rights framework to everyone, regardless of citizenship, and interprets it in light of international human rights commitments; ${ }^{2}$ and the Canadian population remains supportive of a broad immigration policy, one of the only major Western democracies where this is still the case. ${ }^{3}$ Canada has embraced multiculturalism, has a proud history of immigration, and its people were awarded the United Nations' High Commissioner for Refugees' Nansen Medal in 1986 in recognition of extraordinary and dedicated service to refugees. ${ }^{4}$ This may be as good as it gets.

Convention Against Torture and Other Cruel, Inhumane or Degrading Treatment or Punishment, Dec. 10, 1984, 1465 U.N.T.S. 85 [hereinafter Convention Against Torture] (accession by Canada on Feb. 8, 1995); Convention on the Elimination of All Forms of Discrimination Against Women, Dec. 18 1979, 1249 U.N.T.S. 13 (ratified by Canada on Dec. 10, 1981) [hereinafter CDAW]; International Covenant on Civil and Political Rights, Dec. 16, 1966, 999 U.N.T.S 171 [hereinafter ICCPR] (accession by Canada on May 19 1976); International Covenant on Economic, Social and Cultural Rights, Dec. 16 1966, 993 U.N.T.S. 3 (accession by Canada on May 19, 1976); International Convention on the Elimination of All Forms of Racial Discrimination, Dec. 21 1965, 660 U.N.T.S 195 (ratified by Canada on Oct. 14, 1970).

Canada also voted in favor of ratifying the Universal Declaration of Human Rights, which is not considered one of the core instruments because of its declaratory status. Universal Declaration of Human Rights, G.A. Res. 217 (III) A, U.N. Doc A/RES/217(III) (Dec. 10, 1948) [hereinafter UDHR]. But, see International Convention for the Protection of All Persons from Enforced Disappearance, G.A. Res., U.N. Doc. A/61/177 (Dec. 20, 2006); International Convention on the Protection of the Rights of All Migrant Workers and Members of their Families, Dec. 18, 1990, 2220 U.N.T.S. 3 [hereinafter ICRMW], which are the only two of the nine core instruments in which Canada does not participate. The ICRMW is of particular importance for noncitizens but has yet to be ratified by any major migrant-receiving state. For further commentary on why this is so, see CATHERINE DAUVERGNe, MAKING PEOPLE ILlEGaL: WHAT GLOBALIZATION MEANS FOR MIGRATION AND LAW 9.28 (2008).

2. Canadian Charter of Rights and Freedoms, Part I of The Constitution Act, 1982, being Schedule B to the Canada Act, 1982, c. 11 (U.K.). The ruling that Canadian Charter of Rights and Freedoms applied to everyone within Canadian territory is one key aspect of Singh v. Minister of Emp. \& Immigr., [1985] 1 S.C.R. 177 (Can.), decided three years after the Charter came into effect. Early Charter jurisprudence established that international human rights norms were one source of Charter interpretation. The key noncitizen case to date in this regard is Canada (Att'y Gen.) v. Ward, [1993] 2 S.C.R. 689 (Can.).

3. A population survey shows that Canada is still more supportive of immigration across a range of indicators than all other countries in North America and Europe. The study also shows that the Canadian population is less supportive of immigration than in earlier years. See TRANSATLANTIC TRENDS: IMMIGRATION (2010), http://trends.gmfus.org/ immigration/doc/TTI2010_English_Key.pdf. But see Nicholas Keung, Immigrants Fitting in Well (Mostly), Canadians Say, ToronTo STAR, Feb. 4, 2011, at A16 (discussing how although Canadians remain generally in support of immigration, a divide over support of Muslim immigration still exists).

4. The Nansen Medal, now called the Nansen Refugee Award, is named after the first League of Nations High Commissioner for Refugees, and is awarded annually by the 
Against this backdrop, it is particularly important to understand why noncitizens in Canada often do not benefit from the protections offered by international human rights. Indeed, in an important series of high-level decisions over the past decade, the Supreme Court of Canada has lagged behind the (former) House of Lords, ${ }^{5}$ the High Court of Australia, ${ }^{6}$ the Supreme Court of New Zealand, ${ }^{7}$ and the United States Supreme Court ${ }^{8}$ in integrating international standards into its analysis and decision making when it comes to questions of key rights for foreigners. This is not to say that outcomes have consistently been worse for noncitizens in the Supreme Court of Canada, although this is often the case.

The key point is, rather, that the Supreme Court of Canada presently appears less likely to engage with international human rights norms either as a direct source of rights entitlements or as an interpretive device for Canadian constitutional rights, at least in cases that relate to noncitizens. ${ }^{9}$ The list of issues where the Supreme Court of Canada has lagged behind one, many, or even all of these courts is extensive and includes a number of rights that have been identified as particularly important to noncitizens. ${ }^{10}$ For example, on the crucial issue of deportation to face a risk of torture, the Supreme Court of Canada ruled that while international law establishes an absolute

United Nations High Commissioner for Refugees. See Archive of Past Nansen Winners, UNHCR, www.unhcr.org/pages/49c3646c467.html (last visited Feb. 12, 2012).

5. A \& Others v. Sec'y of State for the Home Dep't, [2004] UKHL 56, [2005] 2 A.C. 68 (H.L.) 92-93 (appeal taken from Eng.) (commonly known as the "Belmarsh detainees" case).

6. See Al-Kateb v Godwin [2004] HCA 37 (Aust].) (ruling that the indefinite detention of a stateless person is constitutional); Plaintiff S157/2002 v Commonwealth [2003] HCA 2 (Austl.) (upholding the Migration Act of 1958).

7. See Att'y Gen. v Zaoui [2005] NZSC 38 (ruling that a refugee can only be expelled when thought to pose a serious threat to the security of New Zealand).

8. See Zadvydas v. Davis, 533 U.S. 678 (2001) (ruling that that indefinite detention of immigrants is subject to Constitutional limitations); Hamdan v. Rumsfeld, 548 U.S. 557 (2006) (ruling that the Bush military commission to try detainees in Guantanamo Bay is illegal and lack the protections required by the Geneva Convention and the U.S. Uniform Code of Military Justice).

9. Catherine Dauvergne, Why the Charter is Failing Non-citizens in Canada (forthcoming 2012) (on file with author) This paper analyzes all the Supreme Court of Canada cases concerning rights claims by noncitizens since the Canadian Charter of Rights and Freedoms (Part I of the Constitution Act, 1982 being Schedule B to the Canada Act 1982 (U.K.), 1982, c. 11) came into force in 1982).

10. For example, through inclusion in the ICRMW, supra note 1. For a discussion outlining this theory of the value of this Convention which, to a great extent, repeats rights commitments made in generally applicable documents but ties them to the specific circumstances of migrant workers, see Ryszard Cholewinski, The Human and Labor Rights of Migrants: Visions of Equality, 22 GEO. IMMIGR. L.J. 177 (2008). 
prohibition on removal in this circumstance, Canadian law provides a narrow opening in which the executive branch can balance the risk of torture against Canadian public interest and may deport, without judicial intervention, in rare but appropriate cases. ${ }^{11}$ With regard to indefinite detention without trial, the Supreme Court of Canada approved the Immigration and Refugee Protection Act provisions that can lead to this possibility for noncitizens only, as long as the detention is regularly reviewed by the Immigration and Refugee Board. ${ }^{12}$ In 1999, the Court ruled that the commitment of the Convention on the Rights of the Child to the best interests of children does not require any particular recognition in immigration decision making because it is adequately infused into Canadian statutory interpretation. ${ }^{13}$ Similarly, the Supreme Court declined to review the Federal Court of Appeal's ruling that Canadian immigration law does not contain a right to family reunification. ${ }^{14}$ In 2011, the Court upheld legislation that excludes agricultural workers from unionization and collective bargaining. ${ }^{15}$ This ruling is particularly relevant to noncitizens because of its sectoral application. In each of these cases, there are established international human rights commitments that supported the position asserted by the noncitizens before the Court. These arguments were either explicitly rejected or passed over without comment.

Given this pattern of results at the Supreme Court of Canada, a more thorough analysis is warranted to assess whether, indeed, noncitizens in Canada have meaningful access to the international human rights commitments the government of Canada has made. This paper presents the results of one part of a broader research project that seeks to explain the failure of international human rights norms for noncitizens in Canada. The overall project has approached this explanation in three ways. First, I analyze decisions of the highest-level appellate courts (the Supreme Court of Canada and the Federal Court of Appeal); second, I investigate the policy-making work of the national government; and, finally, I look specifically at the work of the Immigration and Refugee Board of Canada. The first tranche of data from the Immigration and Refugee Board is the focus of this paper.

11. Suresh v. Canada (Minister of Citizenship \& Immigr.), 2002 SCC 1, [2002] 1 S.C.R. 3, para. 129 (Can.).

12. Charkaoui v. Canada (Citizenship \& Immigr.), 2007 SCC 5, [2007] 1 S.C.R. 350, para. 110 (Can.).

13. Baker v. Canada (Minister of Citizenship \& Immigr.), [1999] 2 S.C.R. 817, para. 69 (Can.).

14. See de Guzman v. Canada (Minister for Citizenship \& Immigr.), [2006] 3 F.C.R. 655, (Can. Fed. C.A.), leave to appeal denied, [2006] F.C. 31333 (Can. S.C.C.).

15. Ontario (Att'y Gen.) v. Fraser, 2011 SCC 20 (Can.). 


\section{CANADA'S IMMIGRATION AND REFUGEe BOARD: WHy IT MATTERS}

The Immigration and Refugee Board of Canada (IRB) was created in 1989. It is currently the largest administrative tribunal in Canada, responsible for approximately 50,000 decisions annually. ${ }^{16}$ During the time frame of this research, the IRB was organized into three divisions, although its structure is set to change to four divisions in December 2011.17 The largest division is the Refugee Protection Division (RPD), which is responsible for first-instance refugee decisions. The bulk of the work of the Immigration Division is made up of detention reviews (mandated at regular intervals for every person in immigration detention) ${ }^{18}$ and inadmissibility hearings (one way of determining whether a noncitizen is barred from entering or remaining in Canada). ${ }^{19}$ The Appeal Division primarily hears sponsorship appeals and appeals from removal orders. ${ }^{20}$ Approximately sixty percent of all decisions are refugee determinations made by the RPD. ${ }^{21}$ Decision makers are

16. The IRB's total number of decisions annually has ranged from 34,673 to 62,301 over the nine years of our dataset, 2002 to 2010 . The annual average during this period was 48,752. These figures are reported in successive editions of the IRB's Annual Performance Report. See Publications, IMMigr. \& REFugeE BD. CAN. (Nov. 11, 2011), http://www.irb-cisr.gc.ca/Eng/brdcom/publications/Pages/index.aspx.

17. Immigration \& Refugee Protection Act, S.C. 2001, c. 27, § 151 (Can.). The Refugee Appeal Division has been a part of Canadian law since 2002 when the Immigration \& Refugee Protection Act (IRPA) came into effect, but successive governments have chosen not to implement it. The failure to implement has been strongly criticized by the advocacy community. The best example of this criticism is the campaign by the Canadian Council for Refugees which is an umbrella organization for refugee advocacy NGOs in Canada. The Canadian Council for Refugees webpage on the Refugee Appeal Division contains their own report entitled The Refugee Appeal: Is No One Listening?, issued in 2005. Canadian Council for Refugees, The Refugee APPEAL: Is No ONE LISTENING? (2005), http://ccrweb.ca/refugeeappeal.pdf. For more on the Canadian Council for Refugees, see generally Frequently Asked Questions, CAN. COUNCIL REFUGEES, http://ccrweb.ca/ RADpage/PAGE0003.HTM (last visited Feb. 12, 2012). See also Peter Showler, Submission to the Standing Committee on Citizenship and Immigration (2007), available at http://crweb.ca/documents/showler07.pdf; Convention Against Torture, supra note 1, at para. 7.3. In 2009, the Bloc Quebecois introduced in the House of Commons a private member's bill, B. C-291, 40th Parliament, 2d Sess. (Can. 2009), which would have compelled the government to implement the Refugee Appeal Division. On December 10, 2009, C-291 was defeated on third reading following a tied vote in the House of Commons and the House Speaker voting against the Bill. The December 2011 changes are pursuant to the Balanced Refugee Reform Act, S.C. 2010, c. 8 (Can.).

18. Immigration \& Refugee Protection Act $\S$ 54-61.

19. Id. $\S \$ 44-45$.

20. See id. $\S \S 62-71$.

21. Between 2002 and 2010, the average percentage of decisions made by the RPD was sixty-seven percent. A further breakdown of this information appears below. We compiled this information from successive editions of the IRB's Annual Performance Report by 
appointed to the IRB in varying ways. During the time frame of this research, members of the Refugee Protection Division and the Immigration Appeal Division were appointed through a "governor in council" appointment process designed to ensure independence and security of tenure (for a fixed term). ${ }^{22}$ In part because of this appointment process, these divisions have been considered to exercise quasi-judicial power within the Canadian constitutional framework. ${ }^{23}$ Members of the Immigration Division are appointed as civil servants. ${ }^{24}$

The IRB's mandate is set out in Canada's Immigration and Refugee Protection Act. This legislation, which came into effect in mid-2002, was the first major overhaul of Canada's immigration law framework in a quarter century. One of the innovations of this legislation was that it introduced as one of its objectives the goal of adhering to international human rights commitments. Section 3(3)(f) of the Act states that " $[t]$ his act is to be construed and applied in a manner that ... complies with international human rights instruments to which Canada is a signatory." This statement is remarkably broad, ostensibly including both instruments that Canada has signed but not ratified and instruments that Canada has ratified but which have not been incorporated by either national or provincial legislatures-key steps for Canada's dualist, federal democracy. The Act also extended protected

consolidating reported numbers given for each division. As referenced above, the Annual Performance Reports are available on the IRB webpage at http://www.irbcisr.gc.ca/Eng/brdcom/publications/Pages/index.aspx; some older editions are now archived but are accessible via the same link.

\begin{tabular}{|l|l|l|l|l|}
\hline & $\begin{array}{l}\text { Immigration } \\
\text { Division }\end{array}$ & $\begin{array}{l}\text { Immigration } \\
\text { Appeal Division }\end{array}$ & $\begin{array}{l}\text { Refugee Protection } \\
\text { Division }\end{array}$ & Total \\
\hline 2002 & 14,078 & 4,113 & $33,399(65 \%)$ & 51,590 \\
\hline 2003 & 13,824 & 5,186 & $43,291(69 \%)$ & 62,301 \\
\hline 2004 & 13,940 & 5,489 & $40,008(67 \%)$ & 59,437 \\
\hline 2005 & 13,247 & 5,624 & $26,870(59 \%)$ & 45,741 \\
\hline 2006 & 13,765 & 6,400 & $19,820(50 \%)$ & 39,985 \\
\hline 2007 & 14,247 & 6,429 & $13,997(40 \%)$ & 34,673 \\
\hline 2008 & 16,197 & 6,211 & $18,160(45 \%)$ & 40,568 \\
\hline 2009 & 15,464 & 6,473 & $26,845(55 \%)$ & 48,779 \\
\hline 2010 & 16,668 & 6,999 & $32,628(58 \%)$ & 56,295 \\
\hline 2011 & 3,632 (Jan-Apr) & 1,783 (Jan-Mar) & $8,229($ Jan-Mar) & \\
\hline
\end{tabular}

22. Governor in council appointments are made by the Federal Cabinet, and members can only be dismissed for cause by the Cabinet. Immigration and Refugee Protection Act $\S 153(1)$.

23. See Cécile Rousseau et al., The Complexity of Determining Refugeehood: $A$ Multidisciplinary Analysis of the Decision Making Process of the Canadian Immigration and Refugee Board, 15 J. REFUGEE STUD. 43, 44 (2002).

24. Immigration and Refugee Protection Act $\$ 172(1)$. 
person status in Canada beyond those who come within the international refugee definition, to include those who fall within the protections of the Convention Against Torture (CAT). ${ }^{25}$

There are two reasons for including the IRB in the broader study. The first is that the overwhelming majority of the decisions that affect the lives of noncitizens in Canada are made by the IRB. Because individuals can only have IRB decisions judicially reviewed by Canada's Federal Court once they have been granted leave, appeal routes from the IRB are starkly limited. In most cases (approximately ninety-eight percent), the IRB decision is the only decision. This is because during the time of this research there was no possible appeal from the IRB decision; and even within the upcoming addition of the Refugee Appeal Division, the appeal avenue remains within the Board. Judicial review can be pursued in the Federal Court only by leave of the court, and leave applications are denied more than eighty percent of the time. ${ }^{26}$ And of course, a successful judicial review most often results not in a new decision, but in a new hearing before the IRB.

The second reason for including the IRB is because of section 3(3)(f). This new provision was heralded as an important advance in Canadian

25. See, Immigration and Refugee Protection Act, S.C. 2001 , c. $27, \$ \S 96-98$ (Can.), for a reproduction of the definition of a refugee from the Convention Against Torture (CAT). Section 97 of IRPA, the (CAT) section, is colloquially referred to as "consolidated grounds" protection. Its formulation is not identical to the (CAT), and it incorporates aspects of the refugee framework. Section 97 reads in full:

97. (1) A person in need of protection is a person in Canada whose removal to their country or countries of nationality or, if they do not have a country of nationality, their country of former habitual residence, would subject them personally

(a) to a danger, believed on substantial grounds to exist, of torture within the meaning of Article 1 of the Convention Against Torture; or

(b) to a risk to their life or to a risk of cruel and unusual treatment or punishment if

(i) the person is unable or, because of that risk, unwilling to avail themself of the protection of that country,

(ii) the risk would be faced by the person in every part of that country and is not faced generally by other individuals in or from that country,

(iii) the risk is not inherent or incidental to lawful sanctions, unless imposed in disregard of accepted international standards, and

(iv) the risk is not caused by the inability of that country to provide adequate health or medical care.

Id. $\S 97$. Under either section 96 or 97 of IRPA, section 98 excludes from protection anyone who would also be excluded by section F in Article 1 of the Refugee Convention. Id. §98.

26. Between 2003 and 2010 , the average number of applications for leave each year was 7668 . These applications were granted (on the basis of annual average grant rates) $17.6 \%$ of the time. Statistics, FED. CT. CAN. (Sept. 30, 2011), http://cas-ncr-nter03.cassatj.gc.ca/portal/page/portal/fc_cf_en/Statistics (providing yearly statistical data). 
immigration law. In the lead up to the new Act taking effect, the IRB did extensive work training decision makers to understand and apply international instruments. ${ }^{27}$ The Board itself clearly envisioned that $3(3)(f)$ would influence its work. Its training materials stated

Traditionally, Canadian courts tended to adjudicate cases on the basis of domestic law only. With the advent of the Charter in 1982, reference to international sources has become commonplace. This is a logical development since most of the rights and freedoms protected in the Charter are also contained in international human rights instruments.

The rules of interpretation relating to international law are complex, but generally, there is a common law presumption that Canada's laws are enacted with the intention of giving force to Canada's international obligations. The recognition of Canada's international obligations with respect to persons who need protection because of violations of their human rights is an important feature of the IRPA [Immigration and Refugee Protection Act]. As stated in the legislation, 3. (3) This Act is to be construed and applied in a manner that ... (f) complies with international human rights instruments to which Canada is a signatory. ${ }^{28}$

Beginning in 2002, the Board anticipated a turn towards international human rights law. Accordingly, one objective of this research is to investigate the significance of that turn. My early hypothesis was that there might be an important "high law"-"low law" distinction in Canadian immigration law. ${ }^{29}$ Douglas Hay's development

27. The IRB produced two guidance manuals in May 2002. The first is entitled Consolidated Grounds in the ImMigration and Refugee Protection ACT: PERSons IN NEED OF PROTECTION: DANGeR OF TORTURE (2002) hereinafter CONSOLIDATED GROUNDS MANUAL TORTURE], and the second entitled, Consolidated GROUNDS IN THE Immigration and Refugee Protection Act: Persons in Need of Protection: Risk to LIFE OR RISK OF CRUEL AND UNUSUAL TREATMENT OR PUNISHMENT (2002), available at http://www.irb.gc.ca/eng/brdcom/references/legjur/Pages/index.aspx.

28. CONSOLIDATED GROUNDS MANUAL TORTURE, supra note 27, at 14.

29. See generally Douglas Hay, Legislation, Magistrates and Judges: High Law and Low Law in England and the Empire, in THE BRITISH AND THEIR LAWS IN THE EIGHTEENTH CENTURY 59, 60-61, 78-79 (David Lemmings ed., 2005); DOUGLAS HaY, Property, Authority and the Criminal Law, in AlBIon's Fatal Tree: Crime AND SocietY IN EIGHTEENTH-CENTURY ENGLAND 17, 22-26, 56-63 (Douglas Hay et al. eds., 2011). 
of this distinction analyzed the way criminal sanctions were and were not applied in eighteenth century England and the Empire. Hay concluded that there was a meaningful gap between the majesty and power of the law at its highest level, and the deployment of penalties, including the death penalty, for low-level property crimes tried in local courts. What is most compelling about Hay's account is his theorization of reasons for this gap and how this explanation illuminates the role of criminal law in English society.

The difference between the stated approach of the IRB, and the high level outcomes in the Supreme Court of Canada, suggested that a similar gap might exist in Canadian immigration law, which would be important to identify and explain, and which might shed light on the role of international human rights in contemporary Canadian society. Indeed, if international human rights were systematically considered, developed and applied by the IRB, an absence of engagement with these rights at the Supreme Court of Canada level would be considerably less significant, given the dominance of the tribunal in decisions that affect the lives of individuals. Unfortunately, this hypothesis was not borne out in the data set of IRB decisions. The data does not offer the rich terrain for analysis that Hay found in his study, but it is worth reporting nonetheless if primarily to confirm that the lack of engagement with international human rights norms at the Supreme Court of Canada seems to be paralleled at the Board.

\section{METHODOLOGY}

The basic objective of the IRB part of the project was to examine how the IRB has used international law since the Immigration and Refugee Protection Act came into effect. The first step in this analysis was to gather all the publically available decisions. Relying on publically available decisions is, of course, somewhat problematic. There were approximately 10,000 decisions made public between July 1, 2002, and December 31, 2010. ${ }^{30}$ This is a small fraction of the nearly half of a million decisions made by the IRB during that time frame, ${ }^{31}$ something smaller than the tip of the iceberg.

30. This number is approximate because we have relied on data base counts, as described in the next paragraph. We did not systematically check all cases that were initially identified in each data base for overlap because the numbers were overwhelming. We did conduct this double check for the nearly one thousand cases ultimately included in our data set.

31. Our table assembling this data appears at supra note 21 . The total number of decisions during the time period of our data set is 446,998 . 
I anticipate, however, that any bias in the choice to make a ruling public will advantage rather than disadvantage our analysis. The IRB publicizes decisions that it considers to be representative of its work, novel, important, or of general public interest. ${ }^{32}$ Decisions that are judicially reviewed by the Federal Court are also made public. I believe, therefore, that decisions that have a strong engagement with international human rights norms are more likely to be released publically as they would meet the criteria of novelty, importance, and public interest. In addition, given the IRB's attention to international human rights norms training, I expect that at least in the earliest years of the new legislation, strong engagement with international human rights norms would be considered to put the IRB in a favorable light. For all these reasons, I anticipate that publicly available decisions will either be generally representative of IRB decision-making patterns, or will over-represent the IRB's engagement with international law.

Accordingly, I am confident in my use of publicly available decisions for this purpose, but it is crucial to recognize that, in one important aspect, publicly available decisions will not accurately reflect the IRB's general trends. In the Refugee Protection Division, written decisions are only required for negative decisions, where refugee status is denied. As a decision must first be written (rather than handed down orally) before it even potentially can be made public, negative decisions will be overrepresented. This bias is born out in the data set, where only 6.3 percent of the decisions were positive, compared with a general acceptance rate of refugee claims during this period of close to forty percent. ${ }^{33}$

IRB decisions are available in the commercial Quicklaw data base, on the publicly available CanLII service and in the IRB's own "Reflex" data base. ${ }^{34} \mathrm{~A}$ full set of IRB decisions from all divisions was collected from each data base, and then checked for duplication. We searched for all decisions that made reference to any international law. Following a preliminary review, we eliminated from the data set decisions that referred only to the Refugee Convention and its 1967 Protocol. ${ }^{35}$ This

32. Interview with Peter Showler, Director of Refugee Forum, former Chairperson of the IRB, at University of Ottawa (Jan. 20, 2012).

33. The acceptance rate for refugee claims in the RPD is a good proxy for the overall success rate in this dataset because $93.6 \%$ of the final dataset are RPD decisions. The success rates for first instance refugee claims are available in the IRB's Annual Performance reports discussed at supra note 21 .

34. See generally CANLII, http://www.canlii.org/ (last visited Jan. 2, 2012); Quicklaw, LEXISNEXIS (2012), http:/www.lexisnexis.ca/en/quicklaw/; RefLex, IMMIG. REFUGEE BD. CAN., http://www.irb-cisr.gc.ca:8080/ReFlex/Issue_Index.aspx (last visited Jan. 2, 2012).

35. Convention Relating to the Status of Refugees, July 28, 1951, 19 U.S.T. 6259, 189 U.N.T.S. 137; Protocol Relating to the Status of Refugees, Jan. 31, 1967, 19 U.S.T. 6223, 606 U.N.T.S. 267. 
Convention is the basis of all refugee decisions in Canada. Thus, it can only be under-represented in the data set, as many decision makers refer only to the sections of the Canadian legislation that incorporate the refugee definition from the Convention. After this adjustment, the final data set for analysis included 966 decisions: 907 from the Refugee Protection Division; 40 from the Immigration Appeal Division; and 19 from the Immigration Division.

Once we assembled the data set, we read through each decision and classified it in a number of ways. Most importantly, we coded each case according to its degree of engagement with international law. The categories include the following:

- None: where an international instrument is mentioned in either the decision's text or a footnote but there is no discussion at all.

- Passing reference: the decision maker acknowledges the international instrument and its possible application but there is no substantive discussion. Typically, there is only one sentence. Most of these cases acknowledge and but do not discuss the CAT.

- Brief analysis: short analysis, usually of the CAT, usually within one paragraph.

- Discussion of international law: a discussion that extends beyond a mere acknowledgement of the existence of potentially relevant instruments; with at least some linking of the law to the facts at hand.

- International law influences the outcome: decision maker draws explicitly on international instruments in articulating the decision. This category is usually a subset of the "discussion" category.

We also coded each case to identify which international instruments were referenced, which party introduced international law, and what the outcome was.

\section{LOOKING AT THE DATA SET}

At the highest level, the most surprising and important outcome of this analysis is that the IRB is making scant use of international law. Over the seven and a half years we examined, and considering approximately 10,000 decisions, only 966 made any reference to international law. Of these, a full 691 decisions were found to have no engagement with the international law cited, and a further eighty-five decisions made only a passing reference to some international instrument. The brief analysis category, including only cases where 
international law had no explicit influence on the decision, accounts for an additional 131 of the cases. This leaves only forty-three cases with a robust discussion of international law, and a mere sixteen decisions where international law influenced the outcome.

\section{Type of Engagement with International Law}

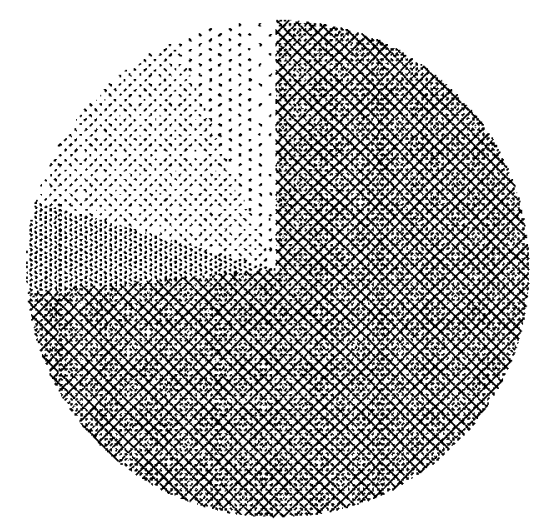

None

it Passing Re ference

$\therefore$ Brief Analysis

$\therefore$ Robust Discussion

Influences Outcome

The introduction of CAT protection into the Canadian legislation accounts for a significant part of the IRB's overt engagement with international human rights. Especially in the years immediately following 2002, decision makers turned to international texts and standards to work through the implications of this provision. 819 of the decisions refer to CAT. Of these, 656 cases had no engagement with the law and a further forty-four had only a passing reference. Five of the 819 cases were decisions where international law influenced the outcome. However, in four of these cases CAT was only one of several international instruments considered. In the sole case where a discussion of CAT was explicitly stated to be central to the outcome, a young man from Burma (the Canadian government recognizes Myanmar) who had been convicted in absentia of assaulting two police officers was granted refugee status; however, he also would have qualified for protected status on the basis of a risk of torture.

Beyond the CAT cases, a wide range of international instruments were considered or referenced in the data set. Thirty-seven different instruments were at least referenced. The Convention on the Rights of 
the Child ${ }^{36}$ had the second most frequent citations with fifty-one, a marked drop below CAT. ${ }^{37}$ Six instruments were referenced between ten and thirty times (in descending order): the Rome Statute, ${ }^{38}$ the International Covenant on Civil and Political Rights, ${ }^{39}$ the Military Charter, ${ }^{40}$ the Universal Declaration on Human Rights, ${ }^{41}$ the European Human Rights Convention, ${ }^{42}$ and the Convention on the Elimination of Discrimination Against Women. ${ }^{43}$ Remarkable on this list are the fifteen references to the European Convention, to which Canada is not a party.

It is also notable that the Tribunal's engagement with international norms has been much lower in more recent years. There are a considerably higher number of cases in the data set from 2003, 2004, and 2005 than in other years. ${ }^{44}$ In part, this likely demonstrates a "learning effect" in the Tribunal-decision makers are more likely to refer to international law given novel situations-which I discuss further in the next section. At this point, it is important to point out that patterns in references to international law do not match up directly with numbers of decisions overall. For example, the three years in the data set with the lowest number of both IRB decisions generally and RPD decisions in particular are 2006, 2007, and 2008. The years with the highest numbers of decisions are 2003, 2004, and 2010.45

36. CROC, supra note 1.

37. Convention Against Torture, supra note 1.

38. Rome Statute of the International Criminal Court, July 17, 1998, 2187 U.N.T.S. 90 (entered into force on July 1, 2002) [hereinafter Rome Statute].

39. ICCPR, supra note 1.

40. Charter of the International Military Tribunal - Annex to the Agreement for the Prosecution and Punishment of the Major War Criminals of the European Axis (London Agreement), U.S.-Fr.-Russ.-U.K., Aug. 8, 1945, 58 Stat. 1544, 82 U.N.T.S. 28.

41. UDHR, supra note 1.

42. Convention for the Protection of Human Rights and Fundamental Freedoms, Nov. 4, 1950, E.T.S. No. 005.

43. CEDAW, supra note 1.

44. It is important to bear in mind that the dataset includes only the second half of 2002 and some of the 2002 decisions are based on the earlier legislation.

45. See the table assembled at supra note 21 . 


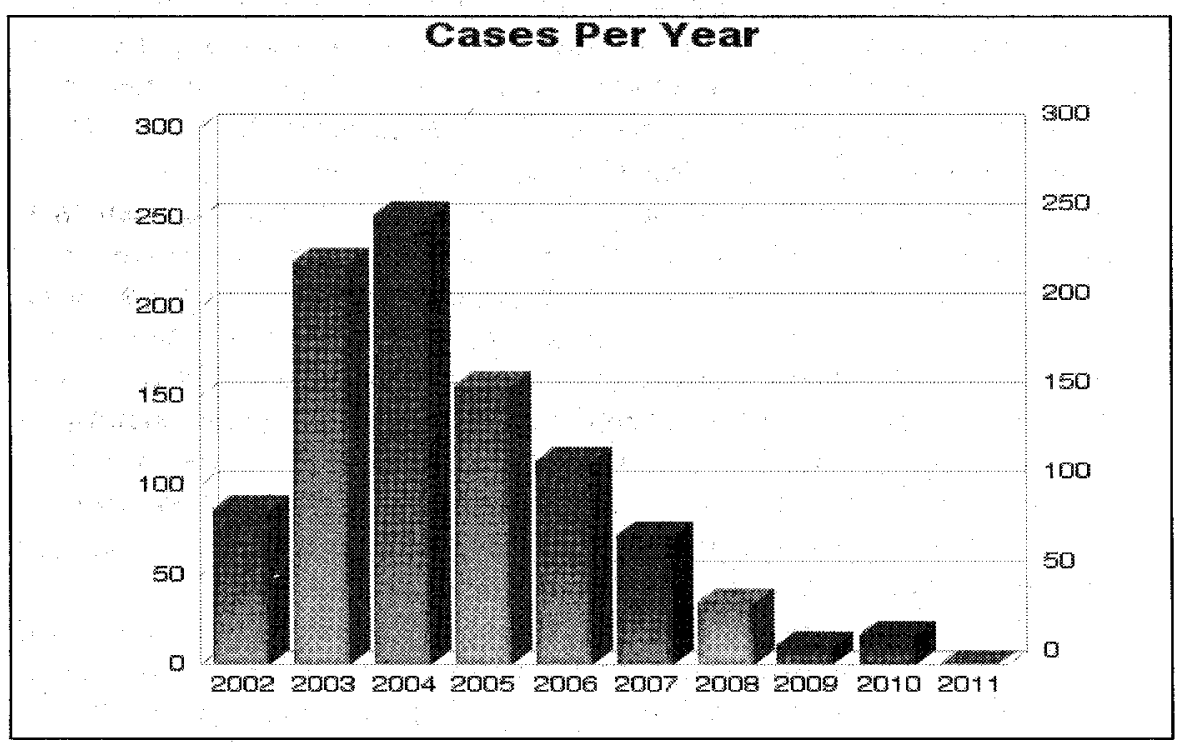

There were two important trends in the data set regarding the overall effects of international law. The first is that a discussion of international law correlates with a positive outcome for the individual. Even in this data set, which is dominated by negative refugee decisions, this trend is discernable. Of the forty-three cases where there was a robust discussion of international law, the claimant was successful in eleven instances. This success rate of more than twenty-five percent is a marked distinction from the 6.3 percent overall in the data set. A similar trend is observable in cases where international law influences the outcome, but since the numbers are so small (five of sixteen cases), translating to percentages is not particularly meaningful. The second trend, which makes the first even more remarkable, is that discussion of international human rights norms is closely tied to refugee exclusions and immigrant inadmissibility. That is, when decision makers are looking to exclude an individual either because of some type of criminality listed in the Immigration and Refugee Protection Act, or under the Refugee Convention's $1 \mathrm{~F}$ provisions (the three categories of which concern international criminality, serious nonpolitical crimes, and acts contrary to the purposes of the United Nations), international law is often referenced. ${ }^{46}$

46. Article 1(F) states,

The provisions of this Convention shall not apply to any person with respect to whom there are serious reasons for considering that: (a) $\mathrm{He}$ has committed a crime against peace, a war crime, or a crime against 
This is not in itself surprising, but it would be heartening to see a balanced use of international human rights norms to, for example, analyze the meaning of persecution within refugee law as well. Persecution is the linchpin of the refugee definition. ${ }^{47}$ Given that this key term is not defined in the Convention, it has been the focus of extensive jurisprudential and scholarly attention. Following James C. Hathaway's seminal 1991 text, The Law of Refugee Status, ${ }^{48}$ the trend in common law jurisdictions at least has been to interpret persecution by reference to international human right standards. Hathaway's paradigm offered the now generally accepted proposition that refugee law was to provide surrogate human norms. In two cases, international law was explicitly found to be determinative on the basis of a brief discussion only. This finding may also indicate that the distinction between our final two categorizations does not always capture a difference in level of reliance on international law. ${ }^{49}$

Five of these cases were Immigration Division admissibility proceedings. In every one of these cases, the applicant was found to be inadmissible. ${ }^{50}$ Analysis of international law was used in reaching the conclusion that the individual was inadmissible on the basis of

humanity, as defined in the international instruments drawn up to make provision in respect of such crimes; (b) He has committed a serious non-political crime outside the country of refuge prior to his admission to that country as a refugee; (c) He has been guilty of acts contrary to the purposes and principles of the United Nations.

Convention Relating to the Status of Refugees, July 28, 1951, 19 U.S.T. 6259, 189 U.N.T.S. 137.

47. A refugee is defined in the Convention as one who,

As a result of events occurring before 1 January 1951 and owing to well-founded fear of being persecuted for reasons of race, religion, nationality, membership of a particular social group or political opinion, is outside the country of his nationality and is unable or, owing to such fear, is unwilling to avail himself of the protection of that country; or who, not having a nationality and being outside the country of his former habitual residence as a result of such events, is Id. at art. 1(A)(2). unable or, owing to such fear, is unwilling to return to it.

48. James C. HathaWAY, The LaW of Refugee Status (1991).

49. Further, of the forty-three cases with a robust discussion of international law, nine occurred in the Immigration Appeal Division. However, in no case did the decision maker state that international law was a reason or a contributing factor to the conclusion on any issue decided in the case.

50. See X v. Canada (Public Safety \& Emergency Preparedness), 2009 CanLII 49232 (Can. B.C.); Canada (Public Safety \& Emergency Preparedness) v. X, 2009 CanLII 59362 (Can. Ont.); Canada (Citizenship \& Immigr.) v. Zamora, 2007 CanLII 12832 (Can. Ont.); Canada (Citizenship \& Immigr.) v. Khan, 2004 CanLII 56758 (Can. Ont.); Re X, 2004 CanLII 56761 (Can.). 
international criminality. ${ }^{51}$ In four of the cases, the specific issue was whether "people smuggling" could be classified as a "transnational crime," the wording that is required under section 37 (1)(b) of the Immigration and Refugee Protection Act.52 Interestingly, these cases did not cluster in the early years of the data set; two were decided in 2004, and two in 2009. ${ }^{53}$ Three of the four cases involve people smuggling from Canada into the United States, and the individuals range from someone who had been convicted of smuggling in American criminal proceedings to someone who is clearly "not a professional people smuggler." 54 The final Immigration Division case involved a former member of the El Salvadoran army who was found to be inadmissible on the basis of his involvement in crimes against humanity-the meaning of which was determined by international standards. ${ }^{55}$

The other eleven cases were in the Refugee Protection Division. In five of these cases, the international law analysis was linked to an exclusion issue; in this respect the decisions are very similar to the Immigration Division rulings. ${ }^{56}$ However, only two of the five claimants were excluded. ${ }^{57}$ In the other three cases, the decision maker's analysis of international law led to the conclusion that the individual was not excludable. Although the numbers here are very small, this finding is almost remarkable in and of itself, as once an exclusion issue is raised, the state prevails in almost ninety percent of cases. ${ }^{58}$ Another group of five decisions were in cases that, for one reason or another, were

51. This finding does not require a finding of guilt, but instead a finding of "reasonable grounds to believe that [the relevant acts] have occurred, are occurring or may occur." Immigration \& Refugee Protection Act, S.C. 2001, c. 27, § 33 (Can.).

52. Immigration \& Refugee Protection Act, S.C. 2001, c. 27, § 37(1)(b) (Can.) states that "A permanent resident or a foreign national is inadmissible on grounds of organized criminality for. . . . engaging, in the context of transnational crime, in activities such as people smuggling, trafficking in persons or money laundering."

53. See X v. Canada (Public Safety \& Emergency Preparedness), 2009 CanLII 49232; Canada (Public Safety \& Emergency Preparedness) v. X, 2009 CanLII 59362; Canada (Citizenship \& Immigr.) v. Khan, 2004 CanLII 56758; Re X, 2004 CanLII 56761.

54. Canada (Public Safety \& Emergency Preparedness) v. X, 2009 CanLII 59362 at para. 72.

55. See Canada (Citizenship \& Immigr.) v. Zamora, 2007 CanLII 12832. This individual had earlier made an unsuccessful refugee claim, but it is not possible to see whether that claim failed on an exclusion ground.

56. See X. (Re), 2005 CanLII 56983 (Can.); Key (Re), 2010 CanLII 62705 (Can. Ont.); X (Re), 2006 CanLII 62239 (Can. Que.); X (Re), 2003 CanLII 55210 (Can. Que.); X (Re), 2003 CanLII 55234 (Can. Que.).

57. See X (Re), 2003 CanLII 55234; X (Re), 2006 CanLII 62239 (concluding that international child abduction was contrary to the purposes of the United Nations, and that the claimant was excluded under Article 1(F)(c)).

58. See Asha Kaushal \& Catherine Dauvergne, The Growing Culture of Exclusion: Trends in Canadian Refugee Exclusions, 23 INT'L J. REFUGEE L. 54, 63-64 (2011). 
atypical of refugee claims in Canada. Three of the claimants involved were citizens of the United States and no U.S. citizen has ever been granted refugee status in Canada. ${ }^{59}$ The fourth case involved a Haitian national child who had arrived in Canada with a woman he later found out was not his mother. ${ }^{60} \mathrm{He}$ had no knowledge of either of his biological parents and had slipped through a loophole in the provision of Canadian citizenship law that is designed to offer a nationality to abandoned children. The final case that I would assess as atypical was that of a married couple who were a Jordanian and a stateless Palestinian, both of whom were granted refugee protection on the basis that their international human right to found a family was breached because neither Jordan nor Israel would allow them to regularize their immigration status as a couple. ${ }^{61}$

This set of cases uses international human rights standards in the role where we would typically expect to find them: in assessing novel facts to analyze the risk of being persecuted. The three remaining cases conform to more "ordinary" refugee claim fact patterns in Canada: the case of the above-mentioned Burmese national fleeing torture; a redetermination of a refugee claim by a man who had been captured by the Shining Path group in Peru and was found not to be excluded because he participated in crimes against humanity only under duress; 62 and the case of a woman fleeing horrific domestic violence, including the rape of one of her daughters. ${ }^{63}$

\section{CONCLUSION: UNDERSTANDING THESE OUTCOMES}

The most interesting part of the exercise begins at.this point. The overwhelming finding that the largest decision-making body for noncitizens in Canada makes very little use of international human rights norms is open to a number of explanations.

One potential hypothesis-which is reflected in important statements of the Supreme Court of Canada-is that international human rights norms are so completely infused into domestic Canadian law that explicit references to them would be unnecessary and therefore

59. See J.H. (Re), 2005 CanLII 56991 (Can.); X (Re), 2010 CanLII 59588 (Can. Ont.); Key (Re), 2010 CanLII 62705 (also counting as an exclusion case).

60. See X (Re), 2004 CanLII 56764 (Can. Que.).

61. See Abuthaher v. Canada (Minister of Citizenship \& Immigr.) No. 810, 2004 R.P.D.D. (Can. Ont.).

62. See X (Re), 2003 CanLII 55210 (Can. Que.).

63. See X (Re), 2002 CanLII 52644 (Can. Que.). Here, the Convention on the Rights of the Child was analyzed in assessing if the best interests of the children were served in finding the mother to be a refugee. Id. This chain of reasoning is itself quite atypical. 
unlikely. ${ }^{64}$ I have rejected this hypothesis for three reasons. First, rulings at the Supreme Court level in noncitizen cases (another part of this study) do not support this idea. Second, within this data set, individual outcomes tended to be more positive when international norms were explicitly referenced and discussed, suggesting that this factor is not "neutral" to decision making. Third, there is widespread concern in the advocacy community that noncitizens in Canada have inadequate access to international human rights norms. This concern is bolstered by recent findings by international human rights bodies that Canada has breached international human rights obligations towards

64. See, e.g., Baker v. Canada (Minister of Citizenship \& Immigration), [1999] 2 S.C.R. 817, paras. 69-71 (Can.), where Justice L'Heureux-Dubé stated for the majority: Another indicator of the importance of considering the interests of children when making a compassionate and humanitarian decision is the ratification by Canada of the Convention on the Rights of the Child, and the recognition of the importance of children's rights and the best interests of children in other international instruments ratified by Canada. International treaties and conventions are not part of Canadian law unless they have been implemented by statute . . . I I agree with the respondent and the Court of Appeal that the Convention has not been implemented by Parliament. Its provisions therefore have no direct application within Canadian law.

Nevertheless, the values reflected in international human rights law may help inform the contextual approach to statutory interpretation and judicial review. As stated in $R$. Sullivan, Driedger on the Construction of Statutes (3rd ed. 1994), at p. 330:

[T] he legislature is presumed to respect the values and principles enshrined in international law, both customary and conventional. These constitute a part of the legal context in which legislation is enacted and read. In so far as possible, therefore, interpretations that reflect these values and principles are preferred. [Emphasis added.]

The important role of international human rights law as an aid in interpreting domestic law has also been emphasized in other common law countries: see, for example, Tavita v. Minister of Immigration, [1994] 2 N.Z.L.R. 257 (C.A.), at p. 266; Vishaka v. Rajasthan, [1997] 3 L.R.C. 361 (S.C. India), at p. 367. It is also a critical influence on the interpretation of the scope of the rights included in the Charter: Slaight Communications, supra; R. v. Keegstra, [1990] 3 S.C.R. 697.

The values and principles of the Convention recognize the importance of being attentive to the rights and best interests of children when decisions are made that relate to and affect their future. In addition, the preamble, recalling the Universal Declaration of Human Rights, recognizes that "childhood is entitled to special care and assistance." A similar emphasis on the importance of placing considerable value on the protection of children and their needs and interests is also contained in other international instruments. The United Nations Declaration of the Rights of the Child (1959), in its preamble, states that the child "needs special safeguards and care." The principles of the Convention and other international instruments place special importance on protections for children and childhood, and on particular consideration of their interests, needs, and rights. 
noncitizens, and by the absence of any governmental response to these rulings. ${ }^{65}$

A second hypothesis is that this methodology misrepresents what is actually taking place in the tribunal. For the reasons I discussed above, I believe that misrepresentation is likely. However, it is likely to overrepresent the use of international law in the tribunal rather than the inverse. There are several other factors that contribute to appropriately interpreting these decisions. IRB decision makers work in a very stressful environment with high workloads. A significant proportion of them are not legally trained, and they rely on a legal services support division to supply legal analysis and conclusions. IRB decisions are usually quite brief and focus closely on the key issues. All of these factors may contribute to a reason-writing atmosphere where international law may be relied on but not explicitly articulated.

This reason-writing atmosphere is closely intertwined with what can be called a "learning effect." It is clearly observable in our data set that decision makers are more likely to discuss international norms when the norms are newly relevant. This accounts in part-and in slightly differing ways-for both the pattern of engagement with CAT, and for the preponderance of novel cases among those where the decision turns on international law. While the number of Refugee Protection Decisions that rely on section 97 has been approximately consistent over the time of the data set, references to CAT have dropped markedly in recent years.

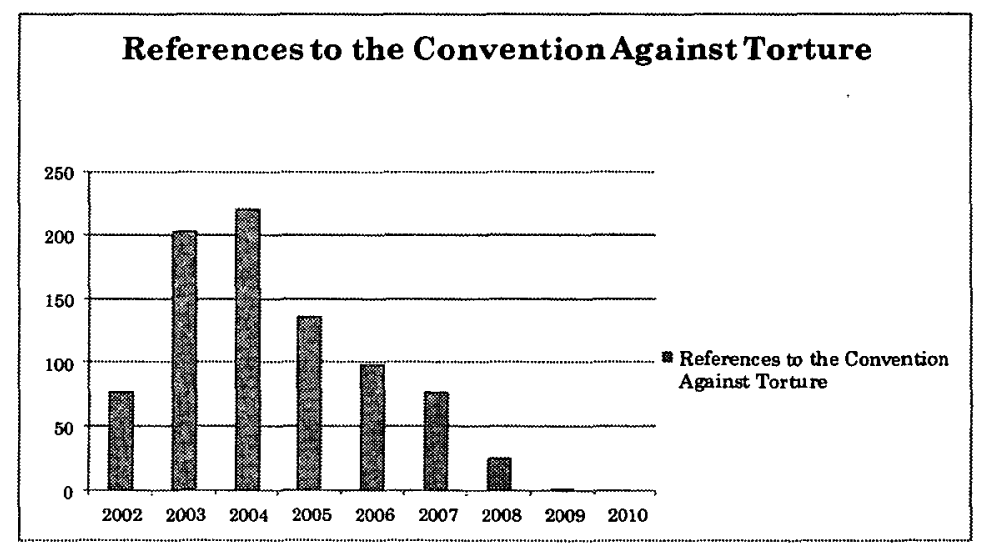

Note: New legislation referencing CAT came into effect on June 28, 2002.

65. Two recent rulings have been on point. See Pillai v. Canada (Minister of Citizenship \& Immigr.), Human Rights Committee, 101st sess., Mar. 14-Apr. 1, 2011, U.N. CCPR, CCPR/C/101/D/1763/2008 (May 9, 2011); John Doe et al. v. Canada, Case 12.586, Inter-Am. Comm'n H.R., Report No.24/11, OEA/Ser.L./V/II.141, doc. 29 (2011). 
A plausible explanation for this pattern is that as decision makers have become more familiar and comfortable with the provisions of CAT, there is less and less reason to refer directly to this instrument. The preponderance issue is, of course, explained inversely. When novel facts arise, decision makers are more likely to make appropriate recourse to international human rights standards to analyze potential new instances of persecution that may fit within the refugee definition.

Accordingly, the question of misrepresentation of what is happening in the IRB must be understood in two ways. First, as stated earlier, publically available decisions likely do over-represent (on a simple percentage basis) the number of cases where international human rights norms are explicitly referenced. However, it is also likely the case that decision makers think about international human rights norms more often than they refer to them. This second effect could be called a citation bias in this study's methodology. That is, the study can only record that to which the decision maker explicitly refers. This is an important point, and it is excessively formalistic to insist that any relevant influence must be explicitly recorded. It is impossible to quantify what the extent of this bias may be, but, given the exceptionally low number of references to international law, a "citationbias factor" is not able to counter the overall conclusions drawn here.

The question of misrepresentation generally is a provocative one. For this reason, as a second step in this study, I plan to conduct interviews with IRB decision makers, managers, and legal services staff. This qualitative analysis will hopefully shed some additional light on the question of how representative the publicly available decisions actually are. I have already investigated whether the use of international instruments is tracked internally, but unfortunately this is not the case.

A third potentially relevant factor could be that lawyers are not raising international law arguments. We did attempt to track this through our data set by coding the cases according to whether the international law was introduced by the individual, the state, or the decision maker. Unfortunately, the results of this coding were not particularly helpful. In eighty-eight percent of cases, the international law appears to have been raised by the decision makers. However, given the nature of IRB reasons-concise and tightly focused-I think this conclusion is unlikely to be reliable. It also does not track with anecdotal analysis from immigration lawyers. It is very difficult to devise a more accurate study of this factor, as bad immigration lawyers-those least likely to raise the greatest possible array of relevant and appropriate arguments-are also the least likely to participate in a research project. Observational research is impossible 
because of high volumes and in camera hearings, and written argumentation is often not submitted to the tribunal.

The marked decline in reliance on international law in the most recent years may also have explanations beyond the learning effect. While it is certainly likely that in the earliest years of the new legislation decision makers felt a greater need to grapple directly with the international instruments, other factors are also relevant. It may be that the interest in international norms declined following the Federal Court of Appeal's ruling that section 3(3)(f) was essentially a codification of existing statutory interpretation practice in Canada and thus would not have the reach that some had envisioned for it. ${ }^{66}$ This decision was handed down in October 2005, so the drop off in number of cases referring to international law had already commenced. Nonetheless, this decision may have some explanatory value. Finally, the failure of appellate courts at the highest levels in Canada to turn to international human rights norms in immigration matters may have subtly communicated to the IRB that initial efforts to engage with international law are simply not necessary.

66. In de Guzman, Justice Evans concluded on behalf of the court:

Paragraph $3(3)(f)$ should be interpreted in light of the modern developments in courts' use of international human rights law as interpretative aids. Thus, like other statutes, IRPA must be interpreted and applied in a manner that complies with "international human rights instruments to which Canada is signatory" that are binding because they do not require ratification or Canada has signed and ratified them. These include the two instruments on which counsel for Ms de Guzman relied heavily in this appeal, namely, the International Covenant on Civil and Political Rights, and the Convention on the Rights of the Child. Thus, a legally binding international human rights instrument to which Canada is signatory is determinative of how IRPA must be interpreted and applied, in the absence of a contrary legislative intention. However, paragraph 3(3)(f) also applies to non-binding instruments to which Canada is signatory. Because the only international instruments relevant to this case are legally binding on Canada, it is not necessary to decide here the effect of paragraph $3(3)(f)$ with respect to non-binding international human rights instruments.

However, in view of the considerations outlined above regarding such instruments, I am inclined to think that Parliament intended them to be used as persuasive and contextual factors in the interpretation and application of IRPA, and not as determinative (emphasis added). Moreover, of these non-binding instruments, not all will necessarily be equally persuasive. This view of paragraph 3(3)(f) also derives support from the Supreme Court of Canada's jurisprudence, to the extent that in the Public Service Employee Relations; Slaight Communications; Baker and Spraytech cases, the Court indicated that it was prepared to give a persuasive and contextual role to non-binding international human rights law in the interpretation of domestic law.

de Guzman v. Canada (Minister for Citizenship \& Immigr.), [2006] 3 F.C.R. 655, (Can. Fed. C.A.), leave to appeal denied, [2006] F.C. 31333 (S.C.C.). 
Despite all of these potential explanatory factors, the numbers in the data set are incredibly stark. In searching for engagement with international human rights norms in decision making about noncitizens in Canada, some trace of international law was found in less than ten percent of publicly available decisions. An engagement that was more than a "passing reference" was found in only two percent of the cases, and reliance on international law as a central aspect of the decision was infinitesimally small at 0.16 percent of cases.

This matters for a number of reasons. First, to return to my starting point, there are many good reasons to think that Canada is likely to be as good as it gets for noncitizen access to international human rights. If that is right, the results are a dismal showing indeed. Second, legal scholars of globalization have heralded the decline of citizenship rights and the rise of international human rights. These findings suggest that this transition is far from realized in Canada. Third, this study shows that Canada's international posture with regard to human rights is at odds with its own practice. This is not surprising to Canadian legal scholars and immigration lawyers, but it is not well understood either within Canada or beyond. Finally, this study also clearly shows that decision makers in all divisions of the IRB are able to engage with international human rights norms, and that the scope for more thorough engagement exists. There is no barrier to this engagement, and given both the recent rulings of the Supreme Court of Canada and the overwhelming importance of the IRB for noncitizens, international human rights advocacy before the IRB is more important than ever. 